\title{
The devil is in the detail: measuring intra-EU labour migration
}

Citation for published version (APA):

Fenwick, C. (2022). The devil is in the detail: measuring intra-EU labour migration. ROA. ROA Research Memoranda No. 001 https://doi.org/10.26481/umaror.2022001

Document status and date:

Published: 17/02/2022

DOI:

10.26481/umaror.2022001

Document Version:

Publisher's PDF, also known as Version of record

\section{Please check the document version of this publication:}

- A submitted manuscript is the version of the article upon submission and before peer-review. There can be important differences between the submitted version and the official published version of record.

People interested in the research are advised to contact the author for the final version of the publication, or visit the DOI to the publisher's website.

- The final author version and the galley proof are versions of the publication after peer review.

- The final published version features the final layout of the paper including the volume, issue and page numbers.

Link to publication

\footnotetext{
General rights rights.

- You may freely distribute the URL identifying the publication in the public portal. please follow below link for the End User Agreement:

www.umlib.nl/taverne-license

Take down policy

If you believe that this document breaches copyright please contact us at:

repository@maastrichtuniversity.nl

providing details and we will investigate your claim.
}

Copyright and moral rights for the publications made accessible in the public portal are retained by the authors and/or other copyright owners and it is a condition of accessing publications that users recognise and abide by the legal requirements associated with these

- Users may download and print one copy of any publication from the public portal for the purpose of private study or research.

- You may not further distribute the material or use it for any profit-making activity or commercial gain

If the publication is distributed under the terms of Article $25 \mathrm{fa}$ of the Dutch Copyright Act, indicated by the "Taverne" license above, 


\section{Maastricht University $\&$ ROA}

\section{The Devil is in the Detail:}

Measuring Intra-EU Labour Migration

Clare Fenwick

\section{ROA Research Memorandum}

ROA-RM-2022/1

Researchcentrum voor Onderwijs en Arbeidsmarkt | ROA Research Centre for Education and the Labour Market / ROA 


\section{The Devil is in the Detail: Measuring Intra-EU Labour Migration}

Clare Fenwick

ROA-RM-2022/1

February 2022

Research Centre for Education and the Labour Market Maastricht University P.O. Box 616, 6200 MD Maastricht, The Netherlands

$\mathrm{T}+31433883647$

secretary-roa-sbe@maastrichtuniversity.nl www.roa.nl 


\section{Abstract}

\section{The Devil is in the Detail: Measuring Intra-EU Labour Migration*}

Freedom of movement is a fundamental principle of the European Union (EU) and yet this key pillar of European integration has become a topic of controversy as member states find their labour markets under pressure. This article examines key trends in intra-EU labour migration and explores what existing migration data has to offer researchers studying EU migration related research questions. Furthermore, it aims to communicate the main limitations of currently available data, with a focus on the lack of quality, disaggregated statistics on the 'category of movement' for intra-EU mobile citizens. Subsequently, this article presents one way in which we have sought to fill this particular gap in migration data. We create two intra-EU labour migration indicators using the European Union Labour Force Survey (EU-LFS) to support researchers aiming to analyse this 'missing' population of interest more effectively. This article explains and presents these labour migration indicators, the method used to produce them, and provides descriptive statistics to show the different trends and patterns between the two groups. Finally, these original indicators are made available for others to make use of in their own research explorations should they wish.

JEL classification: J61

Keywords: labour migration, migration data, free movement, mobile citizens, European Union

Clare Fenwick

Maastricht University

ROA

P.O. Box 616

NL-6200 MD Maastricht

The Netherlands

c.fenwick@maastrichtuniversity.nl

and Studio Europa Maastricht, Onze Lieve

Vrouweplein 22a, 6211 HE Maastricht, The

Netherlands

\footnotetext{
* This study is part of the research programme Social Citizenship \& Migration. An earlier version of this paper was presented at the Interaction between Legal Systems (ILS) lunch seminar series, as well as at the Leiden Interdisciplinary Migration Seminars (LIMS) in Leiden, The Netherlands. I would like to thank all the participants, as well as Olaf van Vliet and Kees Goudswaard for their insightful and helpful comments. This study is based on data from Eurostat, the European Union Labour force Survey (EU-LFS), 2017. The responsibility for all conclusions drawn from the data lies entirely with the author.
} 


\section{Introduction}

Migration has long been a prominent feature of European integration (Castles, de Haas, \& Miller, 2014) and in today's European Union (EU), around 17 million citizens have chosen to make another EU country their home (Eurostat, 2017a). The free movement of people is a fundamental principle of the EU, enshrined under Article 45 of the Treaty on the Functioning of the European Union (Eurostat, 2017a), and under EU law, citizens of EU member states and of the European Free Trade Association (EFTA) are able to reside and participate in the labour market of another EU or EFTA country ${ }^{1}$ on an equal footing with natives (Cappelen \& Midtbø, 2016; Schmidt, Blauberger, \& Martinsen, 2018). This aims to ensure that $\mathrm{EU}^{2}$ labour migrants have equal access to employment, working conditions, and various social and tax related advantages. However, successive EU enlargements have increased the economic heterogeneity within the single market (Dorn \& Zweimüller, 2021) and created challenges for Member States seeking to reconcile their national labour markets with the protection of rights for all EU citizens (Fenwick, 2019). In view of that, the free movement of people has become increasingly politicised and controversial, a crucial talking-point of far-right, populist political parties, and ultimately a major obstacle for future European integration.

Despite the depth of the political debate on freedom of movement and its economic importance, there is a lack of readily available, detailed, and accurate data for crosscountry comparison and to provide policy advice. While this may seem surprising, there are several real-world challenges that the collection of migration data faces, which in practice means that the currently available data has a number of limitations. For example, there is still considerable variation in the way countries choose to identify and define international migrants for statistical purposes, which affects the comparability of aggregate national migration statistics (Fassmann, 2009). International organisations, such as Eurostat and the Organisation for Economic Co-operation and Development (OECD), aim to present internationally standardised and harmonised statistics, but despite attempts to ensure members use internationally accepted definitions and collection methods, this is not always the case in reality.

\footnotetext{
${ }^{1}$ From this point on, for simplicity, the abbreviation 'EU' will also be used to refer to and include the EFTA countries. 2 Who are often referred to as EU mobile citizens in official documents rather than 'immigrants' or 'migrants'.
} 
High quality migration data is essential for facilitating more complex migration research because when more precise research questions are considered, then more precise definitions of the population under study are required. Additionally, more comprehensive research can be used to better understand intra-EU migration and enable national and supra-national governments to deliver effective, evidence-based migration policies. Recently, there have been increasing efforts to construct unique and original datasets on migration that fill certain research gaps and enable authors to answer specific research questions that were previously unanswerable (e.g. Fitzgerald et al. 2014; de Haas et al. 2015; Beine et al. 2015). However, one area of EU migration data that is still missing is on 'category of movement' - for example, whether a person is moving for work, study, or family reasons. In order to contribute to this gap in migration data, we have created specific indicators for intra-EU labour migration using the European Union Labour Force Survey (EU-LFS). This data is essential for contributing to the evaluation and development of EU and national labour migration policy.

This article aims to first highlight key trends in intra-EU labour migration and explore what existing migration data has to offer researchers looking to study migration related research questions. Second, we detail the labour migration indicators that we have created and the method we used to produce them. Finally, we provide those indicators for other researchers to make use of if they wish. This paper thus proceeds as follows; the next section explores the key trends in EU labour migration and highlights what existing researchers have done. Section 3 notes some of the most extensive and useful migration databases and highlights a few of the newer innovations in migration data. Section 4 then discusses the limitations of currently available data and why there was a need to create new indicators for intra-EU labour migration. Section 5 explains our approach and method for generating the EU labour migration indicators and section 6 provides descriptive statistics for those indicators. Finally, section 7 concludes the paper.

\section{Exploring intra-EU labour migration}

Within the last two decades, 13 Central and Eastern European (CEE) countries have joined the EU over three successive rounds of enlargement, expanding the EU from 15 countries to $28^{3}$ and encompassing around 100 million new citizens. In principle, EU

\footnotetext{
332 when including EEA countries. Following Brexit on 2021, the total population with access to freedom of movement stands at over 460 million people across 31 different countries.
} 
accession grants these citizens the right of free movement and all its associated benefits. In practice, the application of this right has not been so clear cut. The 2003 Treaty of Accession made a provision to enable current member states to restrict the labour market access of new member state citizens for up to seven years (known as the 2-3-2 rule). At one point or another, all of the pre-2004 member states have chosen to introduce transitional labour market restrictions for one or more of the post-2004 member states on the grounds of limiting disruption to native citizens' employment and labour market opportunities (Dustmann, Frattini, \& Halls, 2010).

In recent years, Germany has received the largest number of EU citizens, followed by the United Kingdom (UK) and Spain. However, in relative terms, Luxembourg and Switzerland have the highest proportions of EU citizens living and working within their borders. Concerning emigration, the largest groups of mobile citizens in absolute numbers are Romanian, Polish, Italian, Portuguese, and German. Although, as a share of the respective country of origin's resident population, Romanians, Lithuanians, Croatians, Portuguese, and Latvians are the most mobile. These five countries each have between 10 and 20 percent of their resident population abroad (Eurostat, 2017c). The income level of a country is positively correlated with the stock of migrants (Dorn \& Zweimüller, 2021) and EU mobile citizens have, on average, higher employment rates than their respective non-mobile counterparts (Eurostat 2017a). Hence, searching for work abroad may present more opportunities than at home for those who exercise their mobility rights.

Favell (2008) argues that EU enlargement and freedom of movement has enabled a distinctly European migration system characterised by temporary, opportunistic, and circular movements which are "governed by the ebb and flow of economic demand, [rather] than by long-term permanent immigration" (Favell, 2008, p. 703). Although in a case study of the Netherlands, Strockmeijer, de Beer and Dagevos (2019) find that only a very small proportion of Central and Eastern European (CEE) migration can be considered circular and that a larger number actually engage in permanent settlement. Perhaps this suggests a shift in decision making over the long run, from short-term opportunistic movements to long-term settlement as EU freedom of movement matures. A key labour market trend, however, is the inefficient allocation of labour and skills across EU borders because EU10 migrants tend to have on average, higher educational 
attainment than the native population yet often accept lower-skilled jobs contributing to considerable skill mismatch, underemployment, and wasted human capital across the EU. (Galgoczi and Leschke, 2012). Moreover, many CEE labour migrants are in precarious employment or face exclusion and exploitation in the country of destination's labour market (Favell, 2008; Favell \& Hansen, 2010).

Unfortunately, none of these studies are able to draw on any specific statistics to identify the size and scale of stocks and flows of intra-EU labour migration despite calling for politicians to base their policy on demographic trends and dynamics. Where figures do exist, proxies such as total foreign population from CEE countries is used to represent 'labour flows', despite it capturing more than just labour migrants. However, there is no single data source that adequately captures intra-EU labour migration for international, cross-country comparison. A number of newspaper articles, scholarly articles, and reports from various sources rely on total migration statistics, such as total number of EU10 citizens resident in a certain EU15 host nation, to support their arguments when discussing intra-EU labour mobility or CEE workers (e.g. Grabbe, 2001; D'Auria, Mc Morrow and Pichelmann, 2008; Koikkalainen, 2011; Galgoczi and Leschke, 2012; O'Brennan, 2013). The assumption is that total migration is an appropriate proxy for labour migration. A study by Cappelen and Midtbø (2016) explores how EU mobile citizens to Norway have affected public support for the welfare state and argue that intraEU labour immigration is associated with chauvinistic attitudes towards welfare state spending, particularly amongst women. However, the study is unable to directly measure labour migration and so uses the terms intra-EU immigration, intra-EU migrant workers, and intra-EU labour immigration interchangeably even though there is a difference between family and labour migrants, between asylum seekers and students, for example. By providing more detailed indicators for these groups, authors should be better equipped to draw conclusions about them without having to assume that all intra-EU movement is labour migration.

In the cases where data specifically on labour migrants is used, it is usually only for a single country or for a single year, and the data has often been collected specially. For example, in Galgoczi, Leschke and Watt (2009) the chapters all deal with individual, country-specific case studies, and each use a variety of different sources to construct their information on labour migration (e.g. national statistics, work permits, and the EU-LFS). 
In the case of Engbersen et al. (2013), they conducted face-to-face surveys of 654 labour migrants in the Netherlands from Poland, Bulgaria and Romania. Crucially, these papers all study the intended population of labour migrants, but they may not be generalisable across other countries.

Details regarding who is a mobile citizen are useful for countries looking to take a balanced approach towards discussing and managing intra-EU migration. Various social and economic outcomes of EU mobile citizens in different EU member states could be partially explained by the labour market outcomes of these groups and their different distributions and variations across the EU (Lemaitre, Liebig, Thoreau, \& Fron, 2007). For the EU, a comprehensive evidence base is important because of the potential heterogeneous impact intra-EU movement has on Member States and its ability to undermine solidarity. Data that cannot be broken down only has a limited number of uses (Santamaria \& Vespe, 2018) and the ability to disaggregate by these categories of migration is useful for both researchers and policy-makers. Moreover, for researchers aiming to draw conclusions on intra-EU labour migration, the use of the currently available overall flow and stock statistics could lead to over-simplification.

\section{Current migration datasets}

A key source of European migration data for scholars is Eurostat where key international migration statistics are available over a number of years. EU member states are expected to provide Eurostat with data on the number of immigrants disaggregated by citizenship, country of birth, previous usual residence, age, and sex. Eurostat data is mostly provided by EU member states' National Statistical Institutes (NSIs) and estimated from a number of large household sample surveys, such as the European Union Labour Force Survey (EULFS) and the European Union Statistics on Income and Living Conditions (EU-SILC). Besides Eurostat, there are a number of useful sources for aggregate and individual level data on migration that can provide insights into key trends in international migration. To start, the OECD has three comprehensive databases on migration; (1) OECD: International Migration database, (2) Database on Immigrants in OECD countries 'DIOC', and (3) Database on Immigrants in OECD countries and non-OECD Countries 'DIOC-E' which between them provide comparative information on migration stocks and flows, as well as a broad range of demographic and labour market characteristics of immigrants. Other good sources for macro-level indicators on migration are the World Bank's 
DataBank, the UN Global Migration Database by UNDESA, the UN Statistics Division: International Migration data, the UNHCR Population Statistics database, and the publicly available Community Demographic Model International Migration (CDM-IM) dataset (Nawrotzki \& Jiang, 2014). More specific databases include the Asylum Support Office (EASO) for data on asylum seekers, the IOM Displacement Tracking Matrix (DTM) for displaced persons, FRONTEX: Irregular Migration Research Database for irregular migration, and for migrants who have gone missing in the process of migration there is the IOM Missing Migrants Project.

In addition, there have been increasing efforts to construct unique datasets on patterns of migration and national migration policies that fill particular research gaps, however these are not always open access and can be quite specific. Notable efforts by researchers include Fitzgerald et al. (2014) who constructed an extensive database on bilateral migration flows for their paper 'Defying the Law of Gravity' and the research project Determinants of International Migration (DEMIG) that compiled data on migration flows, policies, and visas to track migration policy changes around the world (de Haas et al., 2015). There is also the International Migration Policy And Law Analysis (IMPALA) Database, which is a is a cross-national and cross-institutional project on comparative immigration policy (Beine et al., 2015). Additionally, the Migrant Integration Policy Index (MIPEX) records and codes policies on the integration of international migrants (Huddleston, Bilgili, Joki, \& Vankova, 2015) and (de Haas et al., 2015) code the restrictiveness of immigration policies. However, there are still a number of limitations to currently available migration data ensuring a number of 'black boxes' in migration research still exist.

\section{Limitations of current data on migration}

\subsection{Who is a migrant?}

In 1998, the United Nations Recommendations on Statistics of International Migration broadly defined an international migrant as "any person who changes his or her country of usual residence" (UN-DESA, 2015, p. 1), which encompasses a wide variety of international movements. The UN also adopted a time criterion to distinguish between long-term and short-term: "an international migrant who changes his or her place of usual residence for at least one year is defined as a long-term migrant, while a person who changes his or her place of usual residence for more than three months but less than 
one year is considered to be a short-term migrant" (UN-DESA, 2015, p. 1). Despite this standardised definition, considerable variation in the way countries choose to identify international migrants for statistical purposes still exists. For example, while many EU countries use 'duration of stay' as the de facto approach for identifying immigrants, the qualifying length of the stay varies between countries (Fassmann, 2009).

The majority of EU countries define a migrant as someone who intends to stay between 3 months and 1 year. A number of countries use intended duration of stay because waiting on a measure of actual duration would mean that the data is quickly outdated. However, self-reporting is problematic because many migrants may not know or be prepared to state their intentions (Fassmann, 2009). Furthermore, countries that adhere to the one-year rule (Cyprus, Finland, Sweden, and the UK) do not always identify shortterm migrants, which has the disadvantage of not capturing seasonal migration. In Germany, any person taking up residence is considered a migrant, which captures virtually all types of movement. Poland and Slovakia, on the other hand, use a very restrictive measure for immigration and define a migrant as someone who carries out a 'permanent' change of residence. Very narrow or broad definitions can result in lower or higher levels of migration in relation to other countries (De Beer, Raymer, Van Der Erf, \& Van Wissen, 2010). ${ }^{4}$ This is further complicated because the method a country uses to define or measure the length of stay can also vary. For example, by taking into account the length of the permit granted or by using the date an individual first registered in the destination country (De Beer et al., 2010; Laczko, 2015). Likewise, the definition of an emigrant can also vary. In Austria an individual must leave the country for more than three months, in Belgium it is six months, Finland one year, and in Romania an individual must indicate that they are planning on leaving for good (DeWaard, Kim, \& Raymer, 2012; Fassmann, 2009; Koikkalainen, 2011).

Furthermore, because of 'rights to resettle' individuals with certain ethnic backgrounds settling in particular countries are not considered immigrants but returning nationals. For example, more than 2 million ethnic Germans returned to Germany between 1991 and 2005 (Fassmann, 2009) ${ }^{5}$. Consequently, publicly available data on international migration can be inconsistent ensuring limitations regarding cross-country

\footnotetext{
${ }^{4}$ Discrepancies also arise because some countries include international students in their statistics and others do not.

5 This is also the case for Romanians of Hungarian origin wishing to return and resettle in Hungary, as well as Moldovans originally of Romanian origin returning to Romania
} 
comparability. While the solution would be to require countries to apply uniform duration criteria, such as the UN definition, the reality is not so straightforward. National Statistical Offices tend to assemble data from population registers that was originally gathered at the municipal level and various historical and administrative contexts are then reflected in the way countries choose to collect and record their migration data. Essentially, national data sources tend to reflect national regulatory frameworks in the respective reporting country (Lemaitre, 2005). Plus, there is little incentive to change because the data that is collected and the methods used are usually considered adequate for the administrative, fiscal, and planning needs of the local authority. Consequently, harmonising population register criteria according to international guidelines has been exceedingly difficult (Kraler, Reichel, \& Entzinger, 2015; Lemaitre, 2005).

\subsection{Stock versus flow measures of migration}

The most reliable data sources tend to be on stocks of migrants, e.g. foreign-born as a percentage of the population, rather than flows of immigration. Most EU countries identify the foreign-born population in their censuses making it possible to compare the size of migrant populations (Lemaitre, 2005). However, even for an indicator as simple as the foreign-born population there are still problems regarding definitions and measurement methods. For example, persons who are nationals of their current country of residence but were born abroad are included in the foreign-born data. Moreover, some countries - such as Germany - do not always collect data on foreign-born residents but rather base national statistics on their foreign-population (individuals with a foreign passport)(De Beer et al., 2010; Laczko, 2015; Lemaitre, 2005). This means that once a person has naturalised in their host country, they are no longer considered an immigrant. This can change the size of the reported stock and introduce bias if certain groups with certain characteristics are more likely to naturalise than others.

Data on flows of migrants are more problematic as measurement is difficult ensuring that many countries do not possess reliable statistics. For emigration in particular, outflows of people tend to be unregulated or unchecked and there is little incentive for a migrant to report their movements to the country they have left, thus it is not uncommon for emigrants to still be registered in their country of origin even after living abroad for several years (De Beer et al., 2010). As a result the numbers of emigrants reported by a sending country often differ from the corresponding receiving country's reported 
number of immigrants (DeWaard et al., 2012). Moreover, the recording of national immigration (individuals holding a passport of the country they are immigrating to) is often supressed by the receiving country (De Beer et al., 2010). Consequently, immigration, emigration, and net migration are measures that are subject to a degree of uncertainty.

These difficulties are further compounded in an area of free movement as there are no border checks, no need for to apply for a work or residence permits, and no incentive to register one's movements. Hence, data on intra-EU labour migration is particularly difficult to collect, record, and disseminate because of the complex nature of human movement and the nature of the single market. The result is that many types of intra-EU mobility are miscounted or not even counted at all by official statistics creating an invisible population (De Beer et al., 2010). This reality means that migration statistics are fallible and consequently operationalising migration as a dependent or independent variable can be complicated (De Beer et al., 2010; Eurostat, 2017c; Lemaitre, 2005). As a result, many studies looking to answer research questions about various facets of intraEU labour migration may use the aggregate measure of intra-EU migration as a proxy for labour migration instead, reshape the research question to avoid directly discussing labour migration specifically, or analyse the topic qualitatively.

\subsection{Disaggregating migration statistics}

The ability to disaggregate international migration statistics depends on where the comes from. Statistics such as those provided by the OECD and Eurostat are gathered from a variety of sources depending on the reporting country. Most EU countries base their migration statistics on census data and various administrative sources such as population registers, temporary or permanent residence permits, work permits, health insurance registers, and tax registers. Some also use household sample surveys such as the EU-LFS, mirror statistics or particular estimation methods (Eurostat, 2017c; Lemaitre, 2005). In Germany and the Netherlands, statistics on immigrants are generated from population registers collected at the municipal level. Whereas the UK relies on a passenger survey because there is no official system of local registration (DeWaard et al., 2012). Each source has its own advantages and disadvantages. Producing migration statistics in the EU based upon work permits would exclude mobile citizens from the official numbers as they have free labour market access in other EU member states. Moreover, work permits 
may have little relation to real numbers if they include renewals or if there is a significant backlog. In the case of a census, while it is the most comprehensive way to estimate the number of immigrants, it only happens once every ten years.

Acquiring detailed data on immigration beyond basic age and sex descriptors is incredibly difficult. In particular, if you wish to expand your research into types/categories of movement there is little publicly available data. One exception is inflow of asylum seekers, which is reasonably well recorded by most OECD countries. An asylum seeker is easier to define and record - the 1950 Geneva Convention that provides an international, legal definition of a refugee and the number of asylum applicants is straightforward to count because an asylum seeker must interact with the authorities in their host nation. However, even this can vary between country, some asylum seekers are only counted once they receive refugee status while others are counted earlier in the process (De Beer et al., 2010).

The OECD has endeavoured to deliver statistics on migrant categories and provides some data on migrant workers, freedom of movement, accompanying family of workers, family migration, and humanitarian migration from 2003-2014. Lemaitre (2005) uses data on permanent migration inflows (identified through permanent or indefinitely renewable residence permits) in order to distinguish between different migration flows. However, as with all migration data there is a trade-off - while the method used ${ }^{6}$ provides a gain in cross-country compatibility and an improvement in the detail of information, the data is incomplete because the sources of the information deviate from the standard and issues arise from under-estimation (as it is only permanent-type migration). Furthermore, this source cannot be used for studying categories of migration within the EU because it all falls under 'freedom of movement'. This category encompasses all individuals moving within the EU and Schengen zone, whether they moved for labour or family reasons, and regardless of nationality.

For intra-EU mobility, there is no single perfect data source because of the administrative problems that arise from attempting to track individuals with no incentive to register their cross-border movements and the varying definitions of an immigrant across EU countries. Datasets such as the EU-LFS and EU-SILC have a strong advantage as both

\footnotetext{
${ }^{6}$ See Lemaitre (2005) and Lemaitre et al. (2007)
} 
surveys are highly harmonised and optimised for comparability (Eurostat, 2019b). The disadvantage is that because migrants make up only a very small proportion of the entire population, household surveys can underrepresent specific migrant groups unless the sample size is very large ${ }^{7}$. On the other hand, census and survey data can capture a share of the irregular population who are inevitably excluded from population registers and permit systems.

\section{The European Union Labour Force Survey (EU-LFS): creating intra-EU labour migration indicators}

\subsection{The EU-LFS}

The EU-LFS is the largest, micro-level sample survey that provides information on the labour force participation of residents in private households aged 15 and over. In 2016, the sample size was approximately 4,500,000 individuals across 35 European countries (GESIS, 2019). The sampling units are dwellings, household or individuals depending on the country-specific sampling frames and it provides an important source of statistics regarding trends in the EU labour market and cross-border labour mobility (Eurostat, 2017c) ${ }^{8}$. The EU-LFS is conducted by National Statistical Institutes across Europe and is then processed centrally by Eurostat. The data is collected mainly through direct interviews, although proxy interviews are also possible, and some of the data can be supplied through alternative sources such as administration registers. In some countries, participation in the survey is compulsory (GESIS, 2019). This all ensures that the EU-LFS is a valuable resource for analysing the movement of labour as it uses comparative methodology across all countries, it is regularly conducted, and it provides information on employment, nationality and broad country of birth in a large sample size. The EU-LFS enables us to analyse intra-EU labour migration as it identifies both country of birth and labour force status for individuals, plus it includes population weights. There are two methods for identifying migrants, either country of birth or country of citizenship. Nevertheless, data on the place of birth is the preferred source as there is a large degree of variance in citizenship policy across countries and thus citizenship is often considered

\footnotetext{
7 This can be due to a number of reasons. Migrants tend to have a much higher non-response rate than the overall population due to language difficulties understanding the interviewer or survey or an unwillingness to provide information because of a desire to remain 'under the radar'. Non-response rates are expected to be higher when the migrant is poorly integrated and has fewer socio-economic interactions with wider society. However, as intra-EU labour migrants or mobile citizens have the legal right to live and work in the other member states, the issue that may realistically cause a problem is language difficulties.

${ }^{8}$ More detailed information can be found on the Eurostat website or in the EU-LFS explanatory notes (Eurostat, 2017b).
} 
an unreliable method for measuring mobility (Eurostat, 2018). For example, in order to naturalise in Austria, 10 years of residency is required whereas Belgium requires only three years.

There are three main limitations for our use of the EU-LFS to construct indicators for intra-EU labour migration:

1. Short-term migration such as seasonal migration is unlikely to be captured in the survey because these groups stay for a limited amount of time in their host country (Bela Galgoczi et al., 2009);

2. the possibility that intra-EU labour migrants are underrepresented in the survey;

3. possible bias arising from dropping missing values - if groups that share the same characteristics are systematically dropped.

In our database we create intra-EU labour migration indicators for 16 European countries $^{9}$, from 2004 up until 2016. These countries were selected because they participate in the EU's area of free movement and they consist of key destination countries for intra-EU labour migrants. We would have included Norway, as it has similar characteristics to the countries chosen but the data on migrants on Norway was withheld from the EU-LFS on the basis that the sample of migrants was not considered representative. Moreover, that sample sizes of intra-EU labour migrants in the EU-13 are very small and more likely to be subject to bias.

\subsection{Identifying migrants}

The initial step for creating intra-EU labour migration indicators was to identify migrants. We categorise migrants as persons born outside their current country of residence (foreign-born). When data on country of birth is not available then data on foreign citizens - those with a different nationality than the country they reside in - is used ${ }^{10}$. The labour migration indicators created start in 2004 because of the way the data is presented in the EU-LFS. Prior to 2004, country of birth is labelled as either EU-28 or non-EU due to the anonymisation process undertaken by each reporting country for every individual in the survey. From 2004 onwards, the data for country of birth is presented as broad country groupings under the variable 'COUNTRYB'. The most common groups are: 'Native', 'EU15' (pre-2004 expansion countries), 'NMS10' (2004 expansion countries),

\footnotetext{
${ }_{9}$ Austria, Belgium, Denmark, Finland, France, Germany, Greece, Ireland, Italy, Luxembourg, Netherlands, Portugal, Spain, Sweden, Switzerland, United Kingdom

10 This is the case for Germany only as it withholds data on country of birth.
} 
'NMS3' (Bulgaria, Romania, and Croatia), 'EFTA' (European Free Trade Association), 'Other Europe', 'North Africa', 'Other Africa', 'Near and Middle East', 'East Asia', 'South and South East Asia', 'North America', 'Central America and the Caribbean', 'South America', 'Australia and Oceania'. Some countries reduce these groups into even broader categories because of concerns regarding anonymisation. For example, 'NMS10' and 'NMS3' are combined together under the category 'NMS13'. For our indicators, if 'NMS13' is not available then we combine the two separate figures for 'NMS10' and 'NMS3' to create an indicator for Central and Eastern European migration (EU13). In this case, the two intraEU labour migration indicators are not affected by the groupings. However, for two countries one change in the groupings does have a slight bearing, in Finland and France, the EFTA countries (Switzerland, Norway, Iceland, and Liechtenstein) are counted in 'Other Europe'. Thus, for Finland and France, EFTA migration is missing from the EU-15 \& EFTA labour migration indicator.

\subsection{Identifying labour migrants}

We identify labour migrants through selecting those who are both foreign-born and whose employment status is either employed or unemployed using the variable 'ILOSTAT'11. Using the broad country groups noted earlier, we then create intra-EU labour migration indicators for 16 European countries (EU-15 and Switzerland). We use the information on country of birth and labour force status (employed and unemployed) to identify labour migrants from the EU-15 \& EFTA and EU-13 countries. The variable ILOSTAT provides the labour force status of the individual observations. It is split into five categories; employed, unemployed, inactive, compulsory military service, and persons under 15 . We provide the indicators expressed both as a percentage of the population and as a percentage of the labour force. Table 1 explains the key variables that were created and the method that was used in order to produce them in more detail.

${ }^{11}$ Regarding employment status, there are three mutually exclusive and exhaustive groups - employed, unemployed, and economically inactive - we exclude the category 'inactive' as they are neither employed nor searching for work. 
Table 1: Definition and method for indicators created using the EU-LFS

\begin{tabular}{|c|c|c|}
\hline Indicator & Definition & Method \\
\hline Foreign-born & $\begin{array}{l}\text { A dummy variable to indicate } \\
\text { whether the individual is born in a } \\
\text { foreign country. }\end{array}$ & $\begin{array}{l}\text { Created to identify who is or is not a } \\
\text { migrant using the variable COUNTRYB } \\
\text { (country of birth). An exception is } \\
\text { Germany which chose to suppress this } \\
\text { information. Instead, the variable } \\
\text { 'NATIONAL' (nationality) is used. Thus, } \\
\text { for Germany, the aggregate indicator } \\
\text { represents the foreign population not } \\
\text { foreign-born. }\end{array}$ \\
\hline $\begin{array}{l}\text { EU-15 \& EFTA labour } \\
\text { migration ( } \% \text { of the } \\
\text { total population) }\end{array}$ & $\begin{array}{l}\text { Migrants from the EU-15 and EFTA } \\
\text { (Switzerland, Norway, Iceland, and } \\
\text { Liechtenstein) who are classed as } \\
\text { either employed or unemployed, as } \\
\text { a percentage of the total population } \\
\text { of the destination country. }\end{array}$ & $\begin{array}{l}\text { This indicator was created using } \\
\text { COUNTRYB (country of birth) and } \\
\text { ILOSTAT (labour force status). First, all } \\
\text { observations with ILOSTAT missing } \\
\text { were dropped. Then individuals who } \\
\text { are born in an EU-15 or EFTA country } \\
\text { and 'employed' or 'unemployed'. }\end{array}$ \\
\hline $\begin{array}{l}\text { EU-13 labour } \\
\text { migration (\% of the } \\
\text { total population) }\end{array}$ & $\begin{array}{l}\text { Migrants from the } 13 \text { newest } \\
\text { member states who are classed as } \\
\text { either employed or unemployed, as } \\
\text { a percentage of the total population } \\
\text { of the destination country. }\end{array}$ & $\begin{array}{l}\text { The same method as above, but using } \\
\text { individuals born in the EU-13. }\end{array}$ \\
\hline $\begin{array}{l}\text { EU-15 \& EFTA labour } \\
\text { migration (\% of the } \\
\text { labour force) }\end{array}$ & $\begin{array}{l}\text { Migrants from the EU-15 and EFTA } \\
\text { who are classed as either employed } \\
\text { or unemployed, as a percentage of } \\
\text { the labour force }\end{array}$ & $\begin{array}{l}\text { First, an absolute number for EU-15 \& } \\
\text { EFTA labour migration was created } \\
\text { using the percentage derived above } \\
\text { and population data from the OECD. } \\
\text { Then, this absolute number and data on } \\
\text { the size of the labour force from the } \\
\text { OECD were used in order to provide the } \\
\text { statistic as a percentage of the labour } \\
\text { force. }\end{array}$ \\
\hline $\begin{array}{l}\text { EU-13 labour } \\
\text { migration (\% of the } \\
\text { labour force) }\end{array}$ & $\begin{array}{l}\text { Migrants from the } 13 \text { new member } \\
\text { states, who are classed as either } \\
\text { employed or unemployed, as a } \\
\text { percentage of the labour force }\end{array}$ & $\begin{array}{l}\text { The same method as above, but using } \\
\text { individuals born in the EU-13. }\end{array}$ \\
\hline
\end{tabular}

\section{Descriptive and Comparison Statistics}

This section aims to provide key descriptive statistics for the intra-EU labour migration indicators generated, as well as offer various comparison statistics - where possible - in order to see how the indicators compare to those provided by international organisations. Table 2 displays basic descriptive statistics (mean, standard deviation, minimums, and maximums) for the various variables that were created in the process of 
developing intra-EU labour migration indicators. The table shows that between countries there is larger variation in the sizes of stocks of EU-15 and EFTA mobile citizens than EU13 mobile citizens.

Table 2: Descriptive statistics for 16 European countries (EU-15 plus Switzerland) - from 2004 to 2016

\begin{tabular}{|c|c|c|c|c|}
\hline Variable & Mean & S.D. & Min & Max \\
\hline Foreign-born & 13.13 & 8.70 & 2.07 & 48.44 \\
\hline $\begin{array}{l}\text { EU-15 \& EFTA labour migration } \\
\text { (absolute number) }\end{array}$ & 419922 & 387431 & 30568 & 1470945 \\
\hline $\begin{array}{l}\text { EU-15 \& EFTA labour migration } \\
\text { (percentage of the population) }\end{array}$ & 3.60 & 5.58 & 0.27 & 25.07 \\
\hline $\begin{array}{l}\text { EU-15 \& EFTA labour migration } \\
\text { (percentage of the labour force) }\end{array}$ & 7.26 & 11.59 & 0.61 & 51.29 \\
\hline $\begin{array}{l}\text { EU-13 labour migration } \\
\text { (absolute number) }\end{array}$ & 255272 & 346311 & 1581 & 1809736 \\
\hline $\begin{array}{l}\text { EU-13 labour migration } \\
\text { (percentage of the population) }\end{array}$ & 1.13 & 1.03 & 0.08 & 5.21 \\
\hline $\begin{array}{l}\text { EU-13 labour migration } \\
\text { (percentage of the labour force) }\end{array}$ & 2.30 & 2.12 & 0.15 & 10.33 \\
\hline
\end{tabular}

Figure 1 displays on a map the average EU-15 \& EFTA labour migration as a percentage of the labour force (2004-2016) for the 16 countries. Three countries - Finland, Greece, and Italy - have an average of less than two percent of their labour force made up of EU15 \& EFTA labour migration. The majority of countries have an average level of between two and four percent of their labour force made up of EU-15 \& EFTA mobile citizens. While a few countries - Belgium, Ireland, Luxembourg, Sweden, and Switzerland - have over four percent of their labour force consist of EU-15 \& EFTA mobile citizens. In the case of Luxembourg, this is exceptionally high and the average between 2004 and 2016 hovers around 48 percent. Switzerland is another exception, and that figure is between 15 and 20 percent.

Figure 2 provides the same representation but for EU-13 labour migration. The highest levels of Central and Eastern European labour migration are found in Ireland and Austria, with over four percent of the labour force from CEE countries. This is followed by Italy, Spain, Sweden, and the UK with between two and four percent of the labour force from CEE countries, and the rest have under two percent. On average, over the time period 
chosen, levels of EU-15 \& EFTA migration are higher than CEE countries. However, when we look at the data over time (Figures 3 and 4) there has been a greater increase in CEE labour migration whereas EU-15 has stayed relatively stable over time - an exception is Portugal. For a number of countries - Austria, Italy, Luxembourg, Netherlands, Spain, and United Kingdom - central and eastern European labour migration is on the rise and each year makes up a larger proportion of the labour force. The United Kingdom in particular has seen a dramatic increase in labour migration from the newer member states. A likely reason is because the UK was one of three countries that decided to not impose labour market restrictions (the 2-3-2 rule) on the new member states from the 2004 EU round of enlargement.

\section{Figure 1: Western European labour migration as a percentage of the labour force,} average 2004-2016

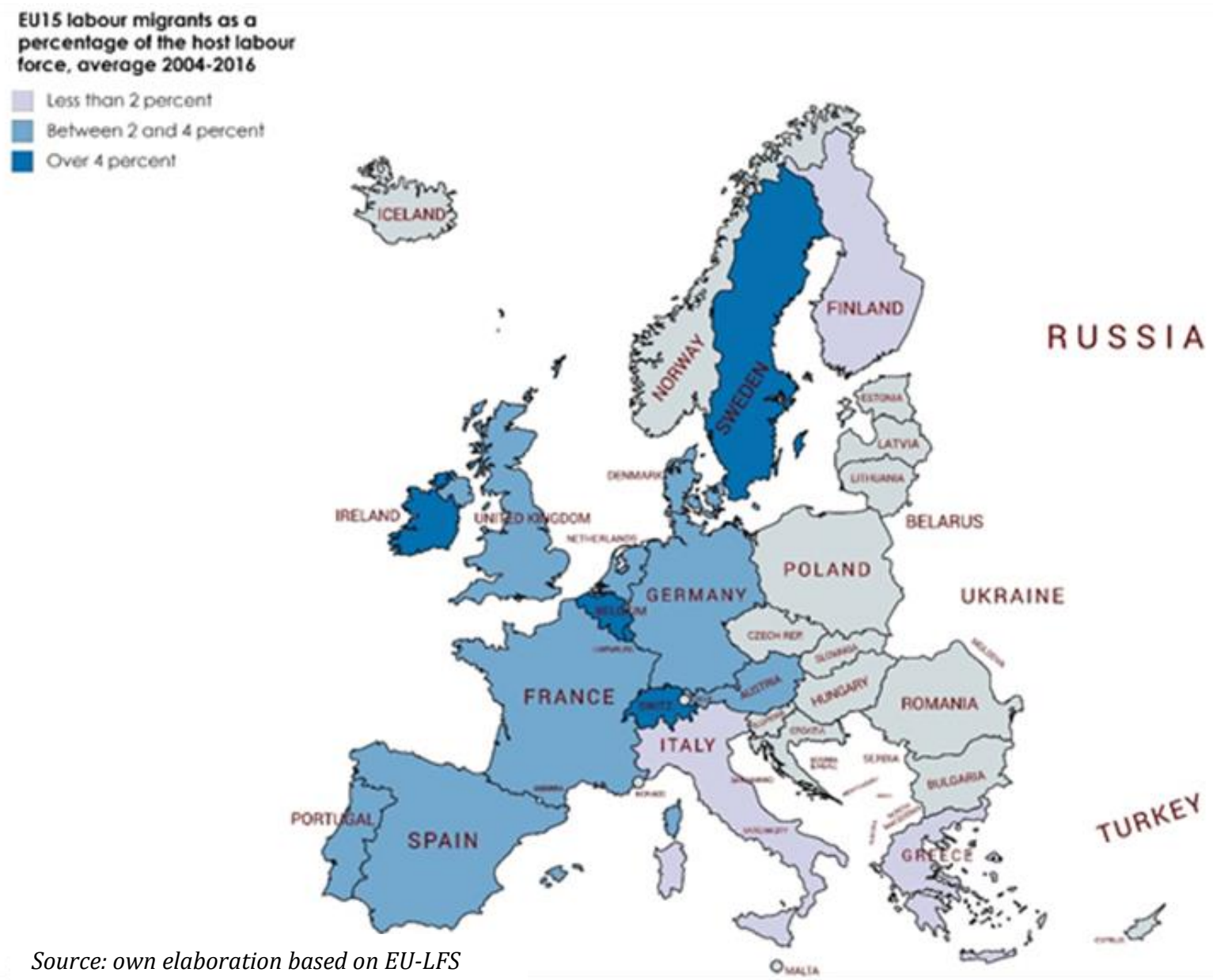

Figures 3 and 4 present the percentage point change in the two labour migration indicators, for EU15 \& EFTA and CEE mobile citizens respectively, from 2005 to 2016. The year 2005 was used because Ireland and Italy do not have the correct data available in the EU-LFS for the year 2004. Thus, for consistency, we have chosen to present the 
change between 2005 and 2016. When comparing the two figures, it becomes evident how CEE labour migration has increased more rapidly over time than Western European migration. This could be for a few reasons, such as because they were mostly new member states in 2004 (some even later) they are just starting to exercise their rights as EU citizens. Perhaps if we compared the increase in migration of the EU-15 from the point of joining we would see something similar. Also, there are differences in levels of unemployment, wealth, and development which may also play a role in driving push-pull migration.

\section{Figure 2: Central and Eastern European labour migration as a percentage of the labour force, average 2004-2016}
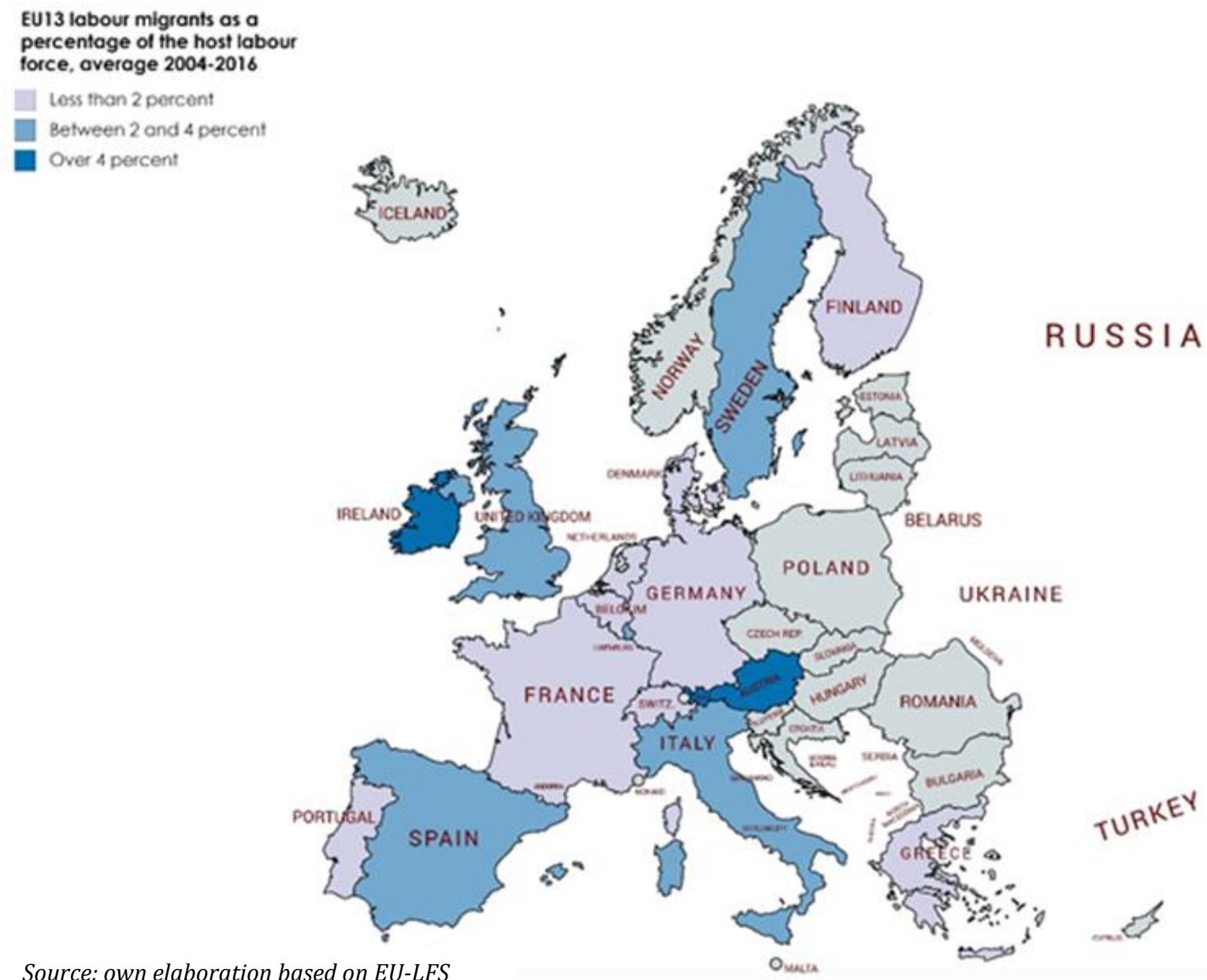

As we have created two new indicators, these statistics cannot be cross-checked with other available statistics. In order to provide an idea as to the reliability and accuracy of our indicators for intra-EU labour migration, we also created a foreign-born indicator which is able to be compared with other readily available migration statistics. In Table 3, we have compared the figure we derived from the EU-LFS with data from the OECD and 
Eurostat on the percentage of foreign-born. Table 3 also presents the correlation statistics between the OECD's foreign-born indicator with the one derived by us from EULFS data in the period 2004 to 2016. Eurostat reports slightly smaller estimates for the size of the migrant population versus the OECD. Both Eurostat and the OECD use similar sources for data collection. Eurostat collects information from the national statistics offices of member states who base their statistics on either administrative data, sample survey data, census data, mirror data, mathematical methods or a combination of these data sources (Eurostat, 2019a). The OECD uses four types of sources; these are population registers, residence permits, labour force surveys and censuses.

\section{Figure 3: The percentage point change in Western European labour migration as a percentage of the labour force, from 2005-2016}

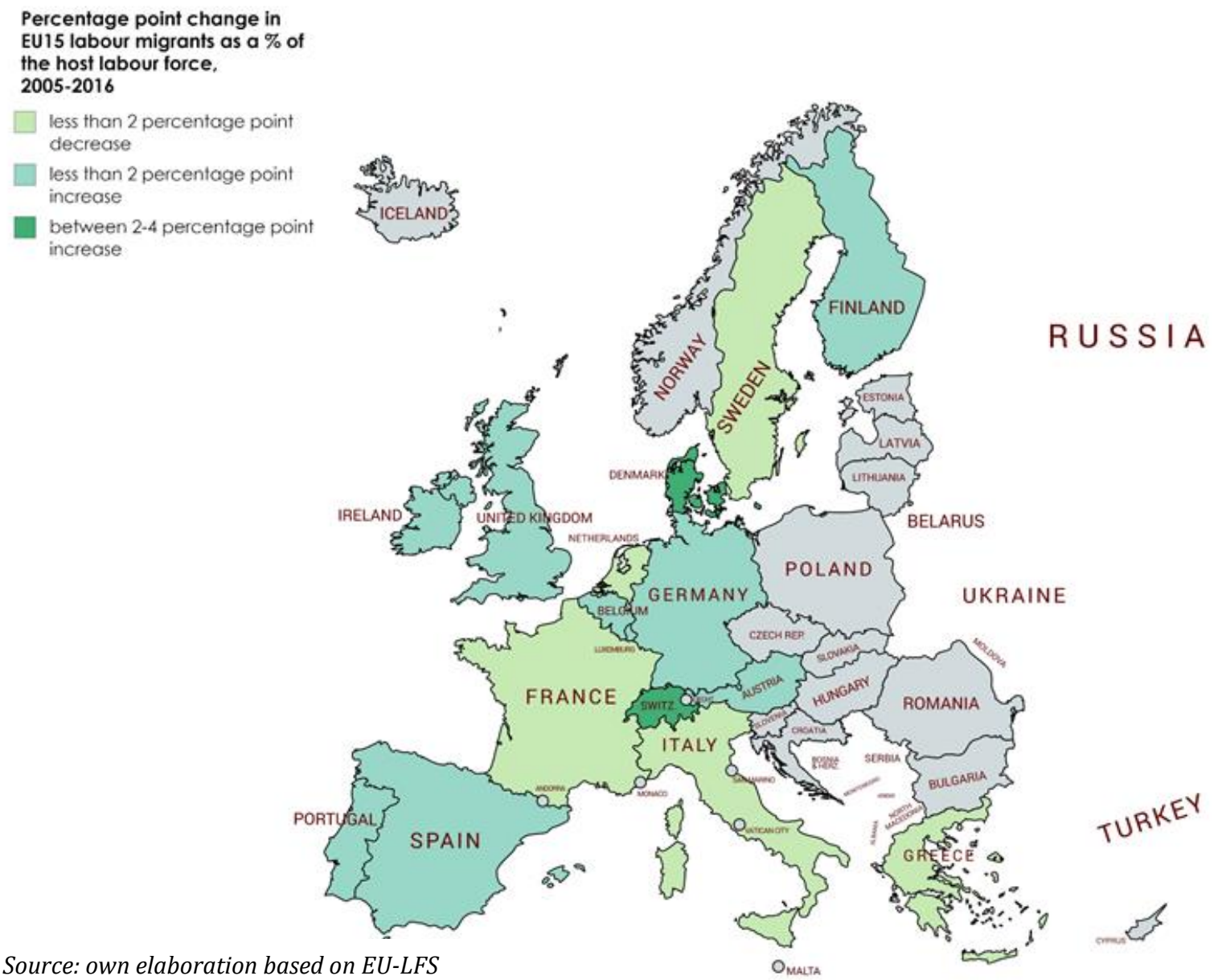

In comparison with the OECD, the EU-LFS provides a lower estimation for the foreignborn population. This could be because migrant populations are hard to reach and are consequently underrepresented, although the weights provided in the survey should adjust for this. Certain countries such as Austria, Switzerland, and the United Kingdom, have EU-LFS estimations of their foreign-born population that are very close to the 
OECD's official statistics. In other countries the gap in the statistics noted in the year 2004 data rapidly closed by 2013. It is possible that sampling methods for the EU-LFS in these countries are more effective than in other countries and that for some countries sampling methods have improved over time. For example, in 2008 several countries (Czech Republic, Denmark, Estonia, Greece, Norway, Poland, Slovenia and United Kingdom) changed their methods, data sources and definitions in order to improve and harmonise data on migration flows.

\section{Figure 4: The percentage point change in Central and Eastern European (CEE) labour migration as a percentage of the labour force, from 2005-2016}

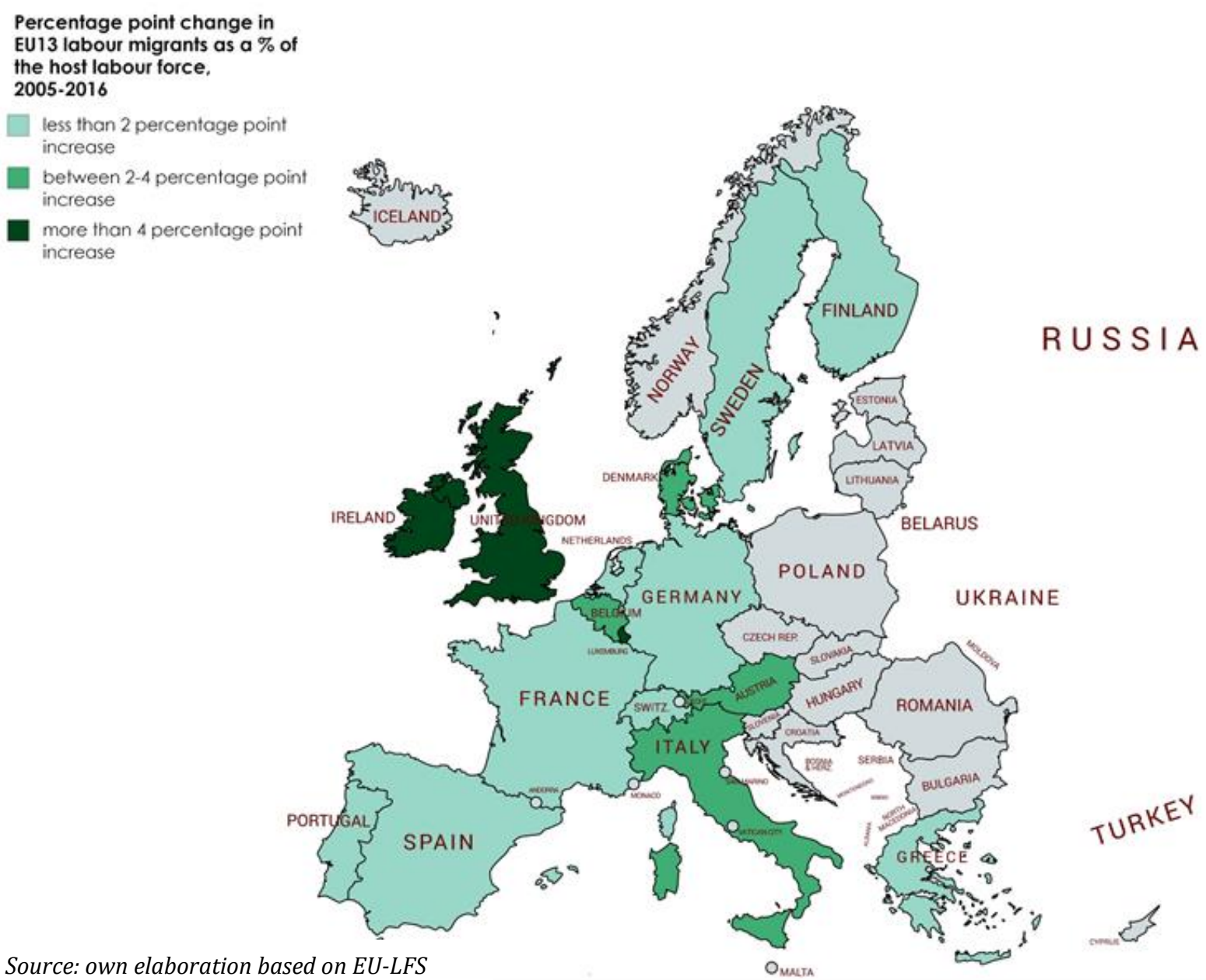

In light of the OECD statistics, Finland and Portugal both appear to underestimate the size of their migrant populations in the EU-LFS. In our copy of the EU-LFS, Finland appears to be missing weights for some observations which may explain this gap. For the Netherlands, the large diversion is caused by drops in the migrant population from outside the EU in the EU-LFS. It could be a problem with the survey design in The Netherlands or the OECD may have not correctly estimated the reduction in this 
particular migration category. Our intra-EU indicators follow the same trend as the OECD's total foreign-born indicator for The Netherlands. Overall, the statistics mostly follow the same trends as the OECD, and they are similar to Eurostat's own estimations of the foreign-born population. The relationships described above can be clearly seen in Figure 5, which provides a graphical comparison between the two figures.

Table 3: Foreign-born comparison statistics*

\begin{tabular}{|c|c|c|c|c|c|c|c|}
\hline & \multicolumn{2}{|c|}{ EU-LFS } & \multicolumn{2}{|c|}{ OECD } & \multicolumn{2}{|c|}{ Eurostat** } & Correlation*** \\
\hline & 2004 & 2013 & 2004 & 2013 & $2004^{ \pm}$ & 2013 & 2004-2016 \\
\hline Austria & 11.26 & 15.47 & 14.14 & 16.7 & & 16.12 & 0.8702 \\
\hline Belgium & 10.98 & 14.15 & 11.71 & 15.51 & & 15.46 & 0.8994 \\
\hline Denmark & 6.21 & 9.5 & 6.35 & 8.48 & & 9.79 & 0.9386 \\
\hline Finland & 2.07 & 3.3 & 3.18 & 5.59 & & 5.15 & 0.9562 \\
\hline France & 9.87 & 11.04 & 11.11 & 12.04 & & 11.50 & 0.8991 \\
\hline Germany ${ }^{¥}$ & $\begin{array}{c}8.55 \\
(2005)\end{array}$ & 8.34 & $\begin{array}{c}12.61 \\
(2005)\end{array}$ & 12.78 & & 11.74 & 0.7927 \\
\hline Greece & $\begin{array}{c}7.84 \\
(2010)\end{array}$ & $\begin{array}{c}6.74 \\
(2012)\end{array}$ & $\begin{array}{c}7.427 \\
(2010)\end{array}$ & $\begin{array}{c}6.58 \\
(2012)\end{array}$ & $\begin{array}{c}11.88 \\
(2010)\end{array}$ & $\begin{array}{c}11.84 \\
(2012)\end{array}$ & 0.9943 \\
\hline Ireland & $\begin{array}{c}8.92 \\
(2005)\end{array}$ & 16.37 & $\begin{array}{l}12.598 \\
(2005)\end{array}$ & 16.42 & & 16.04 & 0.9678 \\
\hline Italy & $\begin{array}{c}6.81 \\
(2008)\end{array}$ & 8.93 & $\begin{array}{c}9.8 \\
(2008)\end{array}$ & 9.46 & & 9.54 & -0.9551 \\
\hline Luxembourg & 32.65 & 41.06 & 32.81 & 43.75 & & 42.35 & 0.9349 \\
\hline Netherlands & 10.58 & 9.83 & 10.66 & 11.63 & & 11.49 & -0.8274 \\
\hline Portugal & 5.37 & 6.86 & 7.39 & 8.2 & & 8.40 & 0.8395 \\
\hline Spain & 7.92 & 12.11 & 10.25 & 13.44 & 8.34 & 13.21 & 0.9890 \\
\hline Sweden & 13.05 & 18 & 12.23 & 15.98 & & 15.41 & 0.9715 \\
\hline Switzerland & 24.41 & 28.95 & 23.52 & 28.3 & & 26.16 & 0.9738 \\
\hline $\begin{array}{l}\text { United } \\
\text { Kingdom }\end{array}$ & 8.73 & 12.86 & 8.9 & 12.26 & & 12.40 & 0.9899 \\
\hline
\end{tabular}

*There are a number of countries with missing data, consequently for some countries data for the years 2004 or 2013 are not available. In these instances, the next closest year is used.

**foreign-born as a percentage of the population has been calculated using Eurostat immigration and population data

***the correlations presented are our own calculations between the OECD and the EU-LFS.

\pm Data not available for most countries until 2009

$¥$ foreign population in EU-LFS, no data for foreign-born is available

Source: Eurostat (2017c, 2017b); OECD (2017)

\section{Conclusion}

The three most recent rounds of EU enlargement have incorporated 13 new member states and around 100 million new citizens into the Union. One of the most important outcomes of this expansion has been the gradual opening up of the EU-15's national 
labour markets to include this new group of mobile citizens. Importantly, open borders within the EU appear to have created new and more diverse patterns of movement, such as circular labour movements driven by economic demand and changing patterns of settlement (Favell, 2008; Strockmeijer et al., 2019). However, across the EU many of these movements remain somewhat invisible as open borders mean there is no need for individuals to apply for a work permit and there are a lack of incentives to register and deregister in the places mobile citizens move between. Thus, despite the high economic importance of intra-EU labour migration, high quality and detailed data on stocks and flows of this movement is lacking, hindering research on this particular subject.

This paper has set out to highlight key trends in intra-EU labour migration and provide a detailed overview of the currently available data on intra-EU labour migration. Moreover, it has sought to explain how we have attempted to fill one particular gap in the statistics with the creation of two novel indicators for use in research. In particular, we created specific indicators for intra-EU labour migration for 16 European countries, from 2004 up until 2016, using the European Union Labour Force Survey (EU-LFS). The EU-LFS is a valuable resource for analysing the movement of labour as it uses comparative methodology across all countries, it is regularly conducted, and it provides information on employment, nationality, and broad country of birth in a large sample size. The EULFS enables us to analyse intra-EU labour migration as it identifies both country of birth and labour force status for individuals.

There are three main limitations in our use of the EU-LFS to construct indicators for intraEU labour migration. First, short-term migration such as seasonal migration is hard to capture in the survey because these groups stay for a limited amount of time in their host country (Bela Galgoczi et al., 2009) and the data we use is only collected on an annual basis. Second, there is the possibility that intra-EU labour migrants are underrepresented due to the likelihood of non-response. Third, in creating the indicators, there could be a possible bias arising from dropping missing values if those that are dropped are from groups that share the similar characteristics. In our comparisons with what data is publicly available, however, they are mostly closely correlated and follow the same trends.

By untangling intra-EU labour migrants from pre-2004 member states and post-2004 member states, this article shows that there are currently different trends between the 
two groups. This data is essential for contributing to the evaluation and development of EU and national labour migration policy. Future research should look to improve our current understanding of intra-EU labour migration and continue delivering new ways of filling the ever-decreasing gaps in migration data. Especially as debates and policy on intra-EU movements could benefit from having a clearer evidence-base in this topic. The full set of indicators on intra-EU labour mobility can be found in the appendix for other researchers to make use of if they wish. 
Figure 5: OECD foreign-born (red) vs EU-LFS generated foreign-born (blue)
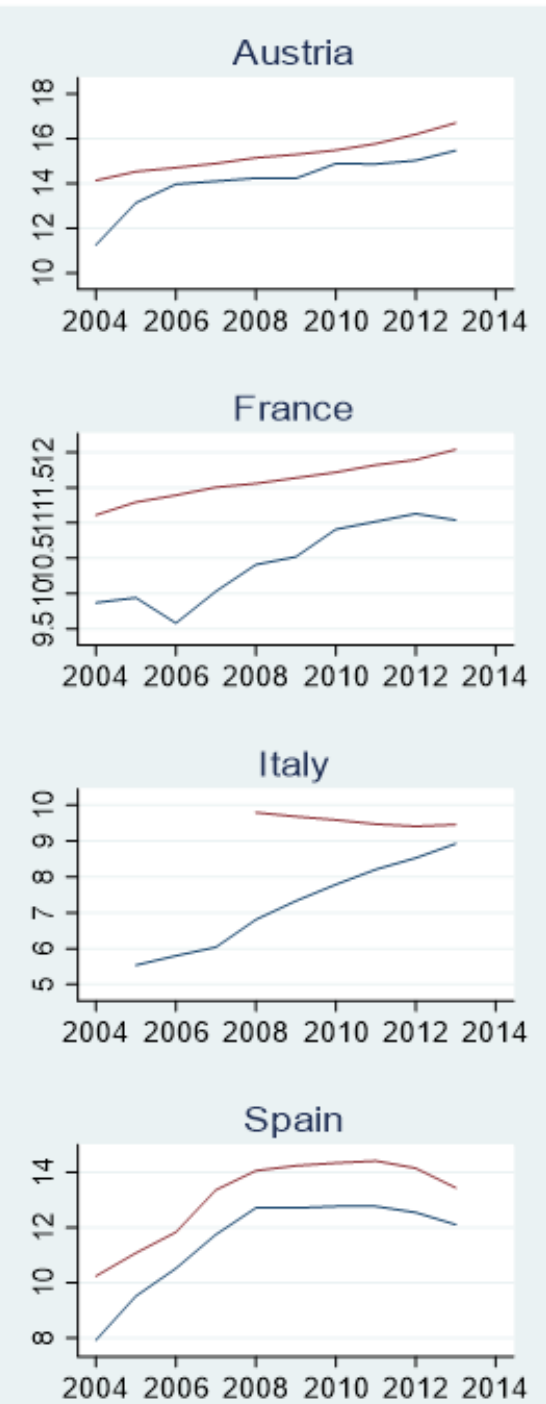

Belgium

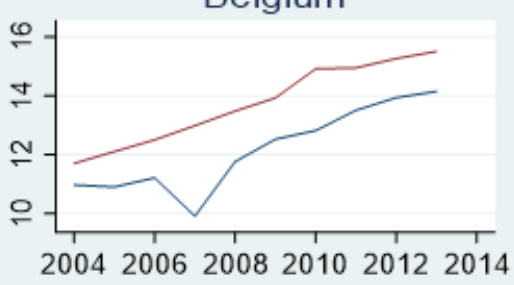

Germany

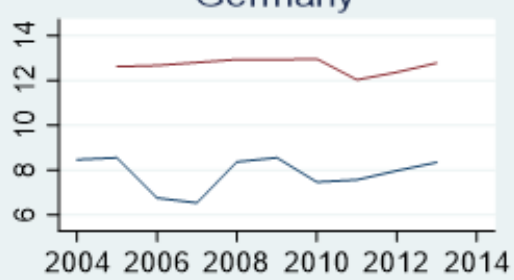

Luxembourg

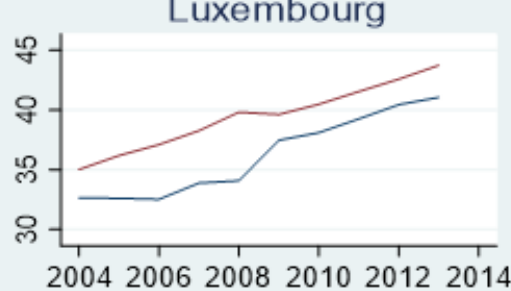

Sweden

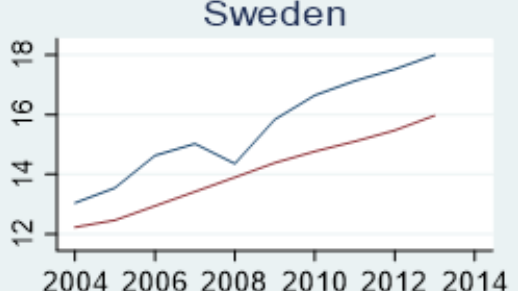

Denmark

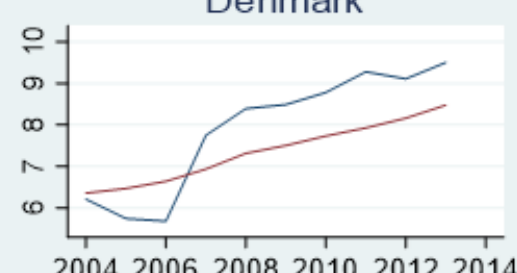

200420062008201020122014
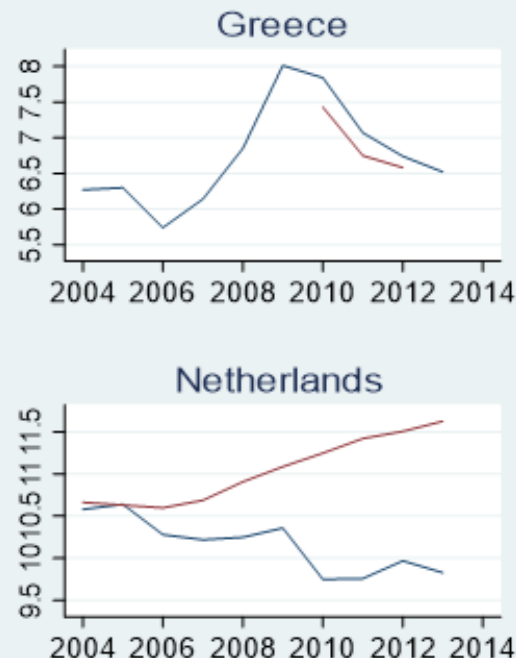

Switzerland

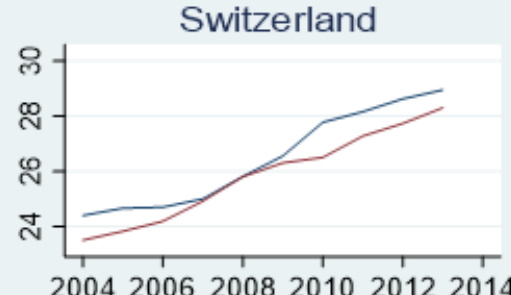

Finland

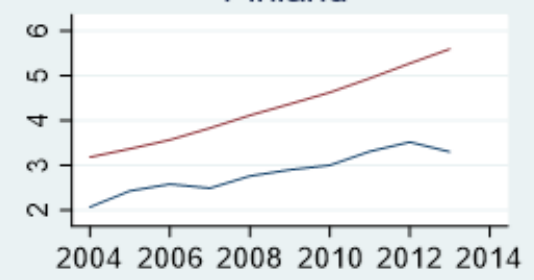

Ireland

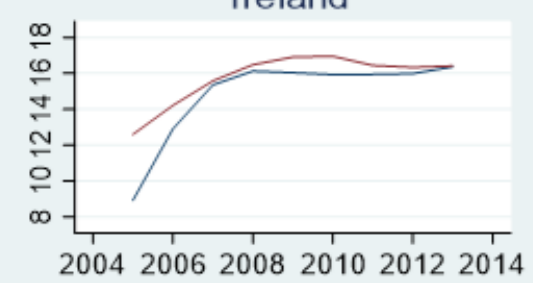

Portugal

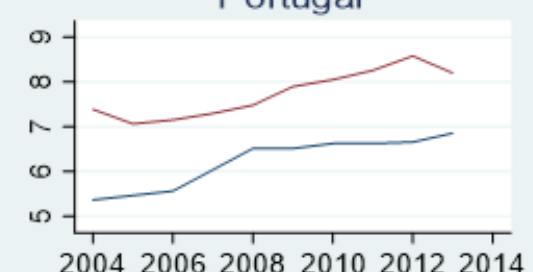

United Kingdom

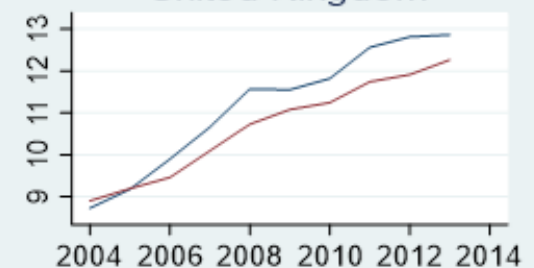




\section{Bibliography}

Beine, M., Burgoon, B. B., Crock, M., Gest, J., Hiscox, M., Mcgovern, P., ... Thielemann, E. (2015). Measuring Immigration Policies: Preliminary Evidence from IMPALA. CESifo Economic Studies, 61(3), 527-559.

Cappelen, C., \& Midtb $\varnothing$, T. (2016). Intra-EU Labour Migration and Support for the Norwegian Welfare State. European Sociological Review, 32(6), 691-703.

Castles, S., de Haas, H., \& Miller, M. J. (2014). The Age of Migration: International Population Movements in the Modern World (5th ed.). Basingstoke: Palgrave Macmillan.

D'Auria, F., Mc Morrow, K., \& Pichelmann, K. (2008). Economic impact of migration flows following the 2004 EU enlargement process: A model based analysis. Retrieved from https://ec.europa.eu/economy_finance/publications/pages/publication13389_en.pdf

De Beer, J., Raymer, J., Van Der Erf, R., \& Van Wissen, L. (2010). Overcoming the Problems of Inconsistent International Migration data: A New Method Applied to Flows in Europe. European Journal of Population, 26, 459-481.

de Haas, H., Natter, K., \& Vezzoli, S. (2015). Conceptualizing and measuring migration policy change. Comparative Migration Studies, 3(15), 1-21.

DeWaard, J., Kim, K., \& Raymer, J. (2012). Migration systems in Europe: evidence from harmonized flow data. Demography, 49(4), 1307-1333.

Dorn, D., \& Zweimüller, J. (2021). Migration and labor market integration in Europe. Journal of Economic Perspectives, 35(2), 49-76. https://doi.org/10.1257/JEP.35.2.49

Dustmann, C., Frattini, T., \& Halls, C. (2010). Assessing the fiscal costs and benefits of A8 migration to the UK. Fiscal Studies, 31(1), 1-41.

Engbersen, G., Leerkes, A., Grabowska-Lusinska, I., Snel, E., \& Burgers, J. (2013). On the Differential Attachments of Migrants from Central and Eastern Europe: A Typology of Labour Migration. Journal of Ethnic and Migration Studies, 39(6), 959-981.

Eurostat. (2017a). EU citizens living in another Member State - statistical overview. Retrieved August 23, 2018, from https://ec.europa.eu/eurostat/statistics-

explained/index.php?title=EU_citizens_living_in_another_Member_State__statistical_overview\#Who_are_the_most_mobile_EU_citizens.3F

Eurostat. (2017b). EU labour force survey - Statistics Explained. Retrieved April 18, 2018, from http://ec.europa.eu/eurostat/statistics-explained/index.php/EU_labour_force_survey

Eurostat. (2017c). Migration and migrant population statistics. Retrieved June 19, 2017, from http://ec.europa.eu/eurostat/statisticsexplained/index.php/Migration_and_migrant_population_statistics

Eurostat. (2018). Migration integration statistics - at risk of poverty and social exclusion. Retrieved October 16, 2018, from https://ec.europa.eu/eurostat/statisticsexplained/index.php/Migration_integration_statistics_-_at_risk_of_poverty_and_social_exclusion

Eurostat. (2019a). Eurostat Metadata. Retrieved December 4, 2019, from https://ec.europa.eu/eurostat/cache/metadata/en/migr_immi_esms.htm

Eurostat. (2019b). Migrant integration statistics introduced. Retrieved July 29, 2019, from https://ec.europa.eu/eurostat/statistics-explained/index.php/Migrant_integration_statistics_introduced

Fassmann, H. (2009). European migration: Historical overview and statistical problems. In H. Fassmann, U. Reeger, \& W. Sievers (Eds.), Statistics and reality: concepts and measurements of migration in Europe (pp. 21-44). Amsterdam: Amsterdam University Press.

Favell, A. (2008). The New Face of East-West Migration in Europe. Journal of Ethnic and Migration Studies, 34(5), 701-716.

Favell, A., \& Hansen, R. (2010). Markets against politics: Migration, EU enlargement and the idea of Europe. Journal of Ethnic and Migration Studies, 28(4), 581-601.

Fenwick, C. (2019). The Political Economy of Immigration and Welfare State Effort: Evidence from Europe. European Political Science Review, 11(3), 357-375.

Fitzgerald, J., Leblang, D., \& Teets, J. (2014). Defying the Law of Gravity: The Political Economy of International Migration. World Politics, 66(3), 406-445.

Galgoczi, Béla, \& Leschke, J. (2012). Intra-EU Labour Migration after Eastern Enlargement and During the Crisis. In SSRN Electronic Journal (No. 2012.13). Brussels.

Galgoczi, Bela, Leschke, J., \& Watt, A. (Eds.). (2009). EU labour migration since enlargement : trends, impacts and policies. Farnham: Ashgate Publishing Limited.

GESIS. (2019). European Union Labour Force Survey (EU-LFS). Retrieved October 7, 2019, from 
https://www.gesis.org/gml/european-microdata/eu-lfs

Grabbe, H. (2001). Profiting from EU enlargement. London.

Huddleston, T., Bilgili, O., Joki, A.-L., \& Vankova, Z. (2015). Migrant Integration Policy Index 2015. Retrieved from http://www.mipex.eu/what-is-mipex

Koikkalainen, S. (2011). Free Movement in Europe: Past and Present. Retrieved December 12, 2018, from Migration Policy Institute website: https://www.migrationpolicy.org/article/free-movement-europepast-and-present

Kraler, A., Reichel, D., \& Entzinger, H. (2015). Migration Statistics in Europe: A Core Component of Governance and Population Research. In P. Scholten, H. Entzinger, R. Penninx, \& S. Verbeek (Eds.), Integrating Immigrants in Europe (pp. 39-58). Heidelberg New York Dordrecht London: Springer, Cham.

Laczko, F. (2015). Factoring Migration into the "Development Data Revolution." Journal of International Affairs, 68(2), 1-17.

Lemaitre, G. (2005). The Comparability of International Migration Statistics: Problems and Prospects. OECD.

Lemaitre, G., Liebig, T., Thoreau, C., \& Fron, P. (2007). Standardised statistics on immigrant inflows results, sources and methods. Retrieved from http://www.oecd.org/migration/mig/38832099.pdf

Nawrotzki, R. J., \& Jiang, L. (2014). Community Demographic Model International Migration (CDM-IM) Dataset : Generating Age and Gender Profiles of International Migration Flows. Retrieved October 7, 2019, from https://opensky.ucar.edu/islandora/object/technotes:519

O'Brennan, J. (2013). The success of the eastern EU enlargement debunks current fears. The Guardian. Retrieved from https://www.theguardian.com/commentisfree/2013/jan/19/success-eastern-euenlargement-debunks-fears

OECD. (2017). OECD Data. Retrieved from https://data.oecd.org/

Santamaria, C., \& Vespe, M. (Eds.). (2018). Towards an EU Policy on Migration Data. Improvements to the EU migration data landscape. Retrieved from https://ec.europa.eu/jrc

Schmidt, S. K., Blauberger, M., \& Martinsen, D. S. (2018). Free Movement and Equal Treatment in An Unequal Union. Journal of European Public Policy, 25(10), 1391-1404.

Strockmeijer, A., de Beer, P., \& Dagevos, J. (2019). Should I stay or should I go? What we can learn from working patterns of Central and Eastern European labour migrants about the nature of present-day migration. Journal of Ethnic and Migration Studies, 45(13), 2430-2446.

UN-DESA. (2015). International Migration Flows to and from Selected Countries: the 2015 Revision. New York. 